九州大学学術情報リポジトリ

Kyushu University Institutional Repository

\title{
Possible Involvement of Pseudomonas Sphingolipid Ceramide N-deacylase in Red Spot Disease of Eels
}

\section{Kita, Katsuhiro}

Laboratory of Marin Resource Chemistry, Division of Marine Biological Chemistry, Department of Bioscience and Biotechnology, Graduate School of Bioresource and Bioenvironmental Sciences, Kyushu University

Sakaguchi, Ke ishi

Laboratory of Marin Resource Chemistry, Division of Marine Biological Chemistry, Department of Bioscience and Biotechnology, Graduate School of Bioresource and Bioenvironmental Sciences, Kyushu University

Furuya, Naruto

Laboratory of Plant Pathology, Department of Applied Genetics and Pest Management, Faculty of Agriculture, Kyushu University

\section{I ida, Takaj i}

Faculty of Agriculture, Miyazaki University

他

https://doi.org/10.5109/24446

出版情報: 九州大学大学院農学研究院紀要. 46 (2)，pp.331-338，2002-02-28. Kyushu University バージョン：

権利関係: 
J. Fac. Agr., Kyushu Univ., 46 (2), 331-338 (2002)

\title{
Possible Involvement of Pseudomonas Sphingolipid Ceramide $N$-deacylase in Red Spot Disease of Eels
}

\author{
Katsuhiro KITA*, Keishi SAKAGUCHI*, Naruto FURUYA** \\ Takaji IIDA $^{\S}$, and Makoto ITO***
}

\begin{abstract}
Laboratory of Marine Resource Chemistry, Division of Marine Biological Chemistry, Department of Bioscience and Biotechnology, and **Laboratory of Plant Pathology, Department of Applied

Genetics and Pest Management, Faculty of Agriculture, Kyushu University, Fukuoka 812-8581 and ${ }^{8}$ Faculty of Agriculture, Miyazaki University, Gakuenkihanadainishi 1-1, Miyazaki 889-2192

(Received October 1, 2001 and accepted November 20, 2001)
\end{abstract}

\begin{abstract}
Strain TK4 capable of producing sphingolipid ceramide $N$-deacylase (SCDase) was isolated from pond in which eel culture was conducted. TK4 was assigned to the genus Pseudomonas on the basis of morphological, physiological and biochemical characteristics and found to be very similar to $P$. anguilliseptica, a known pathogen for red spot disease in eels. 16S rDNA sequence analysis revealed that TK4 and $P$. anguilliseptica should be classified into Group I of the genus Pseudomonas. Interestingly, not only TK4 but also $P$. anguilliseptica had the ability to produce SCDase which hydrolyzes glycosphingolipids and sphingomyelin to generate lyso-forms of sphingolipids. Since lyso-sphingolipids are toxic to many cell lines, SCDase-producing Pseudomonas spp. are suspected to be a potential virulence factor for fish disease including red spot disease (Sekiten- byo) in eels.
\end{abstract}

\section{INTRODUCTION}

Red spot disease (Sekiten-byo) has been reported as an epizootic disease among pond-cultured eels caused by an infection of Pseudomonas anguilliseptica (Wakabayashi and Egusa, 1972). This disease is distinguished from red fin disease, which is caused by an infection of Aeromonas hydrophila (Hoshina, 1962). Eels with red spot disease show a remarkable petechial hemorrhage in the skin of the mouth region, operculla and ventral side of the body. However, how the bacteria cause the disease has not yet been clarified at the molecular level.

We isolated a bacterium Pseudomonas sp. TK4 from eel cultured pond, which produced a novel sphingolipid-degrading enzyme. The enzyme was found to cleave the $\mathrm{N}$-acyl linkage of ceramides of various glycosphingolipids as well as sphingomyelin to generate lyso-sphingolipids and fatty acids. The enzyme was designated as sphingolipid ceramide $N$-deacylase (SCDase) based on its unique specificity (Ito et al, 1995). Lyso-sphingolipids have been known to be toxic; causing not only hemolysis but also various cellular dysfunctions possibly via inhibition of protein kinase $\mathrm{C}$ (Taketomi and Kawamura, 1970; Hannun and Bell, 1987). These results may lead to the hypothesis that

\footnotetext{
* Laboratory of Marine Resource Chemistry, Division of Marine Biological Chemistry, Department of Bioscience and Biotechnology, Graduate School of Bioresource and Bioenvironmental Sciences, Kyushu University

*** Corresponding author (e-mail: makotoi@agr.kyushu-u.ac.jp)
} 
SCDase-producing bacteria are a potential virulence factor for disease in fish. We report here not only TK4 but also Pseudomonas anguilliseptica produce SCDase.

\section{MATERIALS AND METHODS}

\section{Materials.}

$\left[{ }^{14} \mathrm{C}\right]-$ Stearic acid $(54 \mathrm{mCi} / \mathrm{mmol})$ was purchased from American Radiolabeled Chemicals Inc. (U.S.A.) and silica Gel 60 thin-layer chromatography (TLC) plate was from Merck (Germany). $\left[{ }^{14} \mathrm{C}\right]$-Galactosylceramide (GalCer) was prepared by the reverse hydrolysis reaction of SCDase as described previously (Kita et al., 2001; Mitsutake et al., 1998).

\section{Bacterial strains.}

Pseudomonas sp. TK4 was isolated from an eel pond in Miyazaki (Japan) by enrichment culture using a synthetic medium $\left(\mathrm{NH}_{4} \mathrm{Cl} 0.05 \%, \mathrm{~K}_{2} \mathrm{HPO}_{4} 0.05 \%\right.$, and $0.2 \% \mathrm{NaCl}$, pH7.2) containing $0.05 \%$ bovine brain crude gangliosides as the sole source of carbon. TK4 was cultivated at $25^{\circ} \mathrm{C}$ in Tryptone-yeast medium containing bovine-brain acetone powder extracts (medium A: $0.5 \%$ polypeptone, $0.5 \% \mathrm{NaCl}, 0.1 \%$ yeast extract and $0.1 \%$ acetone powder, $\mathrm{pH}$ 7.2) for a specific period.

\section{Physiological and biochemical tests.}

The identification of TK4 was conducted according to the 9th edition of Bergey's Manual of Systematic Bacteriology (Krieg, 1984). Motility, morphology, and gram-staining characteristics were determined by light microscopy. A transmitting electron microscope was employed for observation of flagella with $2 \% p$-tungstic acid. Utilization of each carbohydrate was determined with Hugh-Leifson medium (Hugh and Leifson, 1953). King's medium was used to test for diffusible pigment production (King et al, 1954). Kovacs' oxidase test was employed (Kovacs, 1956). The sensitivity of isolates to antibiotics or other antimicrobial agents was examined by using the disc method with Tri Disc (Eiken, Japan) or Showa Disc (Nissui Seiyaku, Co., Ltd.) on Muller-Hinton agar medium (Difco, USA). The sensitivity to vibriostatic agent $0 / 129$ was tested according to Shewan et al. (Shewan et al., 1954).

\section{Determination of $\mathbf{G}+\mathbf{C}$ content.}

Bacterial DNA was purified by the method of Marmur (Marmur, 1961). Guanine-plus-cytosine $(\mathrm{G}+\mathrm{C})$ content was determined using HPLC as reported by Tamaoka and Komagata (Tamaoka and Komagata, 1984) with some modification. In brief, purified bacterial DNA was dissolved in $10 \mathrm{mM}$ sodium acetate buffer, $\mathrm{pH} 5.3$, containing $2 \mathrm{mM} \mathrm{ZnCl}_{2}$ (II) at a concentration of $1 \mathrm{mg} / \mathrm{ml}$. The solution was heated at $100^{\circ} \mathrm{C}$ for $15 \mathrm{~min}$ and then cooled rapidly in an ice bath. An equal volume of nuclease P1 solution ( $1 \mathrm{mg} / \mathrm{ml}$ in $40 \mathrm{mM}$ sodium acetate buffer, $\mathrm{pH} 5.3$, containing $2 \mathrm{mM}$ zinc chloride) was added to the DNA solution, and the preparation was incubated at $50^{\circ} \mathrm{C}$ for $1 \mathrm{~h}$. The reaction mixture was centrifuged at $15,000 \mathrm{rpm}$ for $15 \mathrm{~min}$ followed by HPLC analysis with a reverse-phase column (YMC-Pack ODS-AQ, 150×6.0 mm I. D., YMC Co., Ltd., Japan). The nucleotides were eluted with $10 \mathrm{mM}$ phosphate buffer, $\mathrm{pH} 3.5$, at a flow rate of 
$1.5 \mathrm{ml} / \mathrm{min}$ at $25^{\circ} \mathrm{C}$. Nucleotides were detected with a UV detector (Hitachi Co., Ltd., Japan) at $270 \mathrm{~nm}$ and peak areas were measured with a HITACHI model L-7200 data processor. A standard mixture of the four deoxyribonucleotides was purchased from Yamasa Shoyu Co., Ltd. (Japan).

\section{Phylogenetic analysis.}

A partial DNA sequence for 16S ribosomal RNA (16S rDNA, ca 1.5-kbp fragment) was amplified by using universal primers, p27f (5'-AGA GTT TGA TCM TGG CTC AG-3') and p1492f (5'-GGC TAC CTT GTT ACG ACT-3'). The amplified PCR product was gel purified, and directly sequenced as reported by Hiraishi (Hiraishi, 1992). Phylogenetic analysis was performed by using both distance and parsimony methods. The distance analysis and trees were generated by neighbor-joining in the program CLUSTAL W (Thompson et al., 1994).

\section{Assay of SCDase activity.}

For the measurement of SCDase productivity, each strain was cultured in $5 \mathrm{ml}$ of medium A at $25^{\circ} \mathrm{C}$ for predetermined periods, the supernatant was obtained as described above, and the enzyme activity was assayed by the hydrolysis of $\left[{ }^{14} \mathrm{C}\right]-$ GalCer. Twenty $\left.\mu\right]$ of enzyme was incubated with the same volume of substrate solution (400 pmol of $\left[{ }^{14} \mathrm{C}\right]$-GalCer in $50 \mathrm{mM}$ phosphate buffer, $\mathrm{pH} 6.0$, containing $1.6 \%$ Triton $\mathrm{X}-100$ ) at $37^{\circ} \mathrm{C}$ for $6 \mathrm{~h}$. One enzyme unit was defined as the amount capable of catalyzing the hydrolysis of $1 \mu \mathrm{mol}$ substrate for $1 \mathrm{~min}$ under the conditions described above. A value of $10^{-3}$ and $10^{-6}$ units of enzyme was expressed as 1 milliunit and 1 microunit, respectively.

\section{TLC analysis.}

Each sample was dried up, dissolved in $15 \mu \mathrm{l}$ of chloroform/methanol=2/1 $(\mathrm{v} / \mathrm{v})$ and applied onto the TLC plate. After the development (solvent system; chloroform/methanol $/ 12 \mathrm{mM} \mathrm{MgCl}_{2}=65 / 25 / 4, \mathrm{v} / \mathrm{v}$ ), the TLC plate was exposed to the IP plate (Fuji Film, Japan) for $3 \mathrm{~h}$ following analysis with a BAS-1500 imaging analyzer (Fuji Film, Japan).

\section{RESULTS AND DISCUSSIONS}

A SCDase-producing bacterium, strain TK4, was isolated by enrichment culture using synthetic medium containing crude bovine brain gangliosides as the sole source of carbon from pond water in which eel culture was conducted. Fig. 1 shows a photograph of Pseudomonas sp. TK4 under an electron microscope. TK4 was a rod-shaped bacterium with a single polar flagellum. The biochemical and physiological properties of TK4 are summarized in Table 1. Judging from these results, TK4 was assigned to the genus Pseudomonas and was found to be very similar to $P$. anguilliseptica, $P$. alcaligenes, and $P$. pseudoalcaligenes. 16S rDNA analysis revealed that these 4 strains belong to Pseudomonas Group I (Fig. 2). It is worth noting that $P$. anguilliseptica is known to be a pathologen of eel red spot disease (Wakabayashi and Egusa, 1972) and TK4 was isolated from the eel-cultured pond, although the $\mathrm{G}+\mathrm{C}$ content (Table 1) and antibiotic sensitivity (Table 2 ) of the two species were clearly different. 


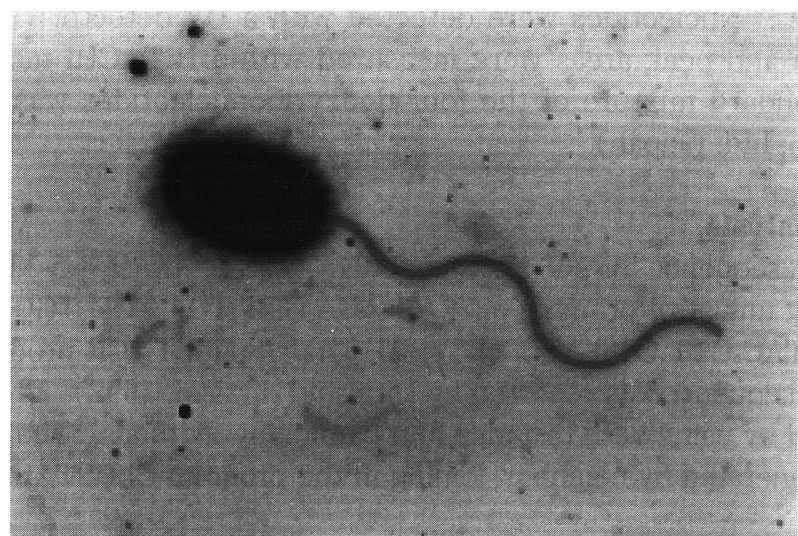

Fig. 1. Electron micrograph of Pseudomonas sp. strain TK4. The cells were stained with $2 \% p$-tungstic acid solution ( $\mathrm{pH} 7.2$ ) and observed under an electron microscope (JEM 100 CXII, JEOL, Japan).

Table 1. Morphological, physiological, and biochemical properties of strain TK4

\begin{tabular}{|c|c|c|c|c|}
\hline Characteristics & TK4 & P. anguilliseptica & P. alcaligenes & P. pseudoalcaligenes \\
\hline Shape & Short rod & Short rod & Short rod & Short rod \\
\hline Motility & + & + & + & + \\
\hline Flagellum & Polar monotrichous & Polar monotrichous & Polar monotrichous & Polar monotrichous \\
\hline Gram staining & - & - & - & - \\
\hline Growth in air & + & + & + & + \\
\hline Catalase & + & + & + & + \\
\hline Oxidase & + & + & + & + \\
\hline $\mathrm{O}-\mathrm{F}$ test & - & - & - & - \\
\hline Color of colony & Yellowish white & Yellowish white & Yellowish white & Yellowish white \\
\hline Growth at $41^{\circ} \mathrm{C}$ & + & + & + & + \\
\hline Arginine dehydrolase & + & + & + & d \\
\hline Production of fluorescence pigments & - & - & - & - \\
\hline Denitrification & + & + & + & $\mathrm{d}$ \\
\hline Degradation of gelatin & + & + & $\mathrm{d}$ & d \\
\hline \multicolumn{5}{|l|}{ Utility of: } \\
\hline Glucose & - & - & - & - \\
\hline Trehalose & - & - & - & - \\
\hline D-xylose & - & - & - & - \\
\hline Maltose & - & - & - & - \\
\hline Saccarose & - & - & - & - \\
\hline Mannitole & - & - & - & - \\
\hline Ethyleneglycole & - & - & - & - \\
\hline Arginine & + & + & + & + \\
\hline Citric acid & + & + & $\mathrm{d}$ & $d$ \\
\hline Urea & - & - & - & - \\
\hline $\mathrm{Mol} \% \mathrm{G}+\mathrm{C}$ in DNA & 66.4 & 62.4 & $64-68$ & $62-64$ \\
\hline
\end{tabular}

+ : positive, - : negative, $\mathrm{d}$ : weakly positive 

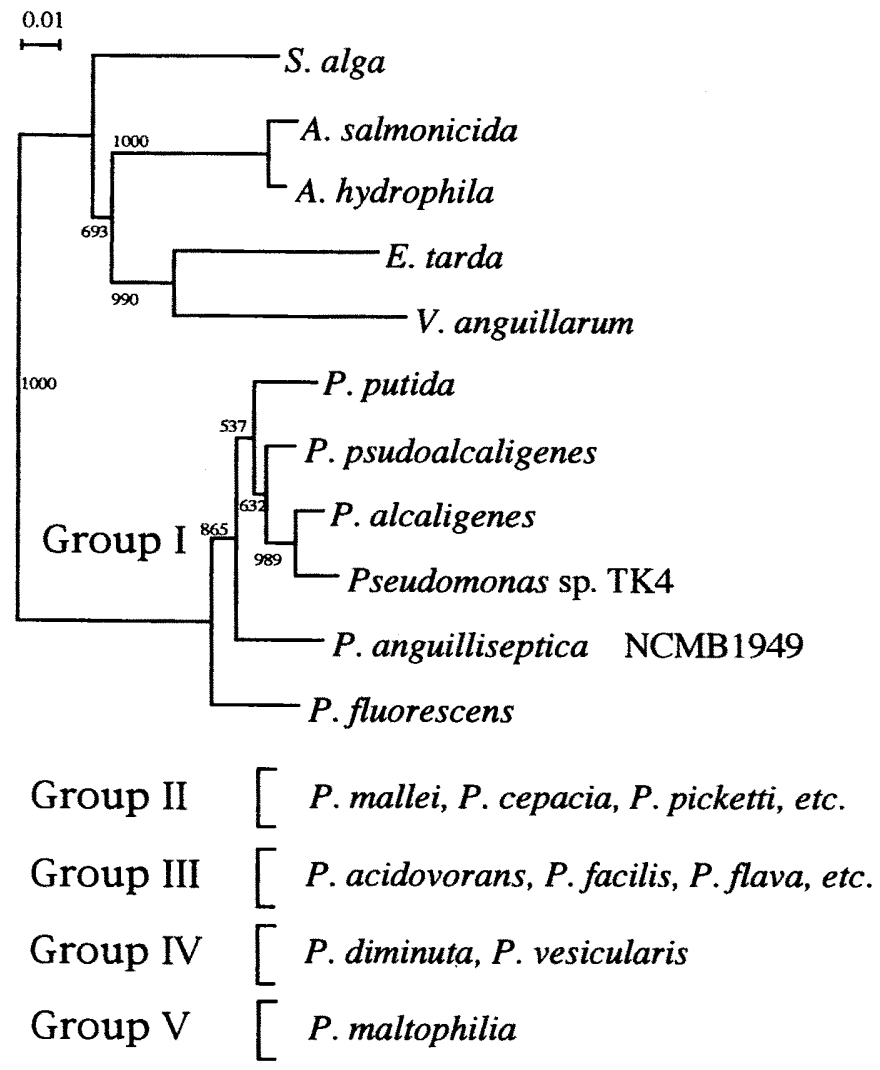

Fig. 2. Phylogenetic tree of Pseudomonas spp. by $16 \mathrm{~S}$ rDNA analysis. The analysis was based on a comparison of approximately 1500 nucleotide bases of 16S rDNA partial sequences in which three different primers were used. The tree was constructed by using the CLUSTAL W algorithm (Thompson et al.).

Table 2. Sensitivity to antimicrobial agents

\begin{tabular}{|c|c|c|}
\hline \multirow{2}{*}{ Antimicrobial agents } & \multicolumn{2}{|c|}{ Strains } \\
\hline & TK4 & P. anguilliseptica \\
\hline Penicillin & - & + \\
\hline Erythromycin & - & $H$ \\
\hline Oleandomycin & - & + \\
\hline Leucomycin & - & $H$ \\
\hline Novoviocin & - & H \\
\hline Chloramphenicol & + & $H+$ \\
\hline Tetracycline & $+H$ & $H$ \\
\hline Kanamycin & $H$ & $H$ \\
\hline Colistin & $H$ & $H$ \\
\hline
\end{tabular}

$+H$ : Strongly sensitive, H: Moderately sensitive, + : Weakly sensitive,

-: Insensitive 
Pseudomonas sp. TK4 has been isolated as an SCDase-producing bacterium (Ito et $a l ., 1995)$ and found to be very similar to $P$. anguilliseptica based on the physiological and biolochemical characteristics in this study. Thus, we examined whether P. anguilliseptica produces SCDase or not. Interestingly, not only TK4 but also $P$. anguilliseptica NCMB1949 released SCDase into the culture supernatant when cultivated in medium A. However, the other 3 species of Pseudomonas and known fish pathogens tested did not produce the enzyme under the conditions (Table 3). Fig. 3 shows the time course for the production of SCDase by TK4 and $P$. anguilliseptica. The enzyme activity released in the culture supernatant by TK4 was detected at 1 day after inoculation of the bacterium and reached a plateau at $2-4$ days, while that by $P$. anguilliseptica reached a maximum in 2 days. It was found that the production of SCDase by the latter was relatively low (Fig. 3), possibly due to the lower growth rate of $P$. anguilliseptica in the medium used.

Lyso-sphingolipids have been known to exert hemolytic (Taketomi and Kawamura, 1970) or cytotoxic activity (Sugiyama et al., 1990). Lyso-sphingolipids were also found to be a potent inhibitor for protein kinase C (Hannun and Bell, 1987) which is known to play an important role in an intracellular signaling cascade. Recently, we reported the apoptosis of Neuro2a cells induced by lyso-sphingolipids with a naturally occurring stereochemical configuration (Sueyoshi et al., 1997; Sueyoshi et al., 2001). In the present study, it was observed that sphingosylphosphorylcholine (lyso-sphingomyelin) and galactosylsphingosine (psychosine) have strong hemolytic activity for fish erythrocytes, although their parental sphingolipids (galactosylceramide and sphingomyelin) nor fatty acids had no effects (Fig. 3).

As previously reported, SCDase can hydrolyze not only glycosphingolipids but also sphingomyelin to generate their lyso-- forms (Ito et al., 1995). Lyso-sphingolipids are hemolytic for various erythrocytes including those of fish and possibly toxic to vertebrates at the cellular level. Thus, SCDase-producing bacteria could be a virulence factor for fish disease, especially red spot disease of eel, because $P$. anguilliseptica, a pathogen causing the disease, was also found to produce SCDase in this study.

Table 3. Activity of SCDase from fish pathogenic bacteria.

\begin{tabular}{lllc}
\hline \multicolumn{1}{c}{ Species } & \multicolumn{1}{c}{ Strain } & \multicolumn{1}{c}{ Source } & SCDase activity $(\mu \mathrm{U} / \mathrm{ml})$ \\
\hline E. tarda & NE8003 (FPC498) & flatfish ascites & - \\
E. tarda & NE8030 (FPC500) & red sea bream gill & - \\
E. tarda & SU226 & eel-cultured pond & - \\
E. tarda & SU100 & eel-cultured pond & - \\
E. tarda & SU138 & eel & - \\
E. tarda & E381 & tilapia kidney & - \\
V. anguillarum & PT87050 & ayu & - \\
A. hydrophila & A9 & eel & - \\
A. hydrophila & A10 & eel & - \\
A. salmonicida & $2-637-1$ & greenling & - \\
P. fluorescens & FPC185 & carp & 5.2 \\
P. anguilliseptica & NCMB1949 & eel blood & 19.0 \\
Pseudomonas sp. & TK4 & eel-cultured pond & \\
\hline
\end{tabular}


(A)

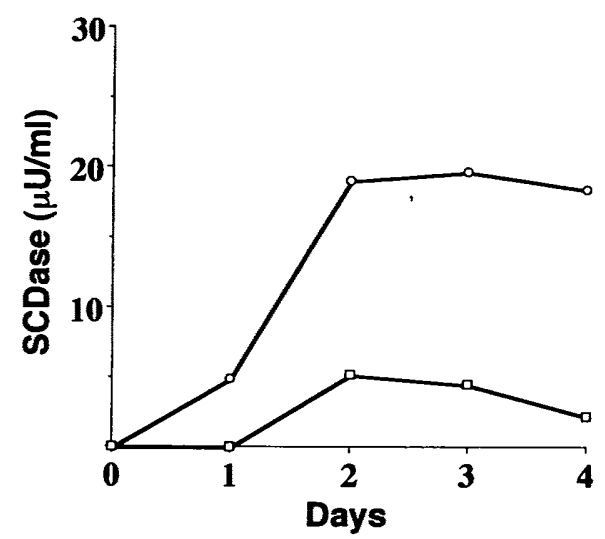

(B)

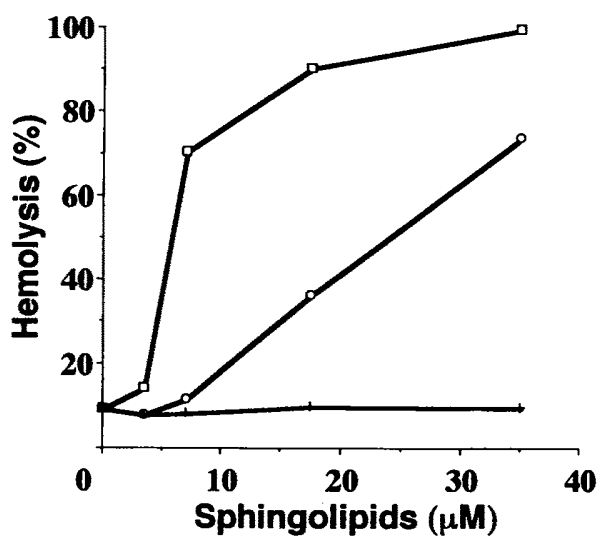

Fig. 3. Production of SCDase by TK4 and $P$. anguilliseptica (A) and hemolysis of carp erythrocytes by lyso-sphingolipids (B).

(A), Each strain was cultured at $25^{\circ} \mathrm{C}$ for the periods indicated and the enzyme activity was assayed as described under "MATERIALS AND METHODS". $O$, TK4; $\square$, P. anguilliseptica. (B), Carp erythrocytes $\left(7.5 \times 10^{6}\right.$ cells $)$ were incubated with appropriate concentrations of lyso-sphingolipids or their parental sphingolipids in $200 \mu \mathrm{l}$ of $20 \mathrm{mM}$ PBS (pH 7.4) at $37^{\circ} \mathrm{C}$ for $30 \mathrm{~min}$. After incubation, $400 \mu \mathrm{l}$ of PBS was added and centrifugation performed at $4{ }^{\circ} \mathrm{C}(800 \mathrm{~g} \times 5 \mathrm{~min})$. The supernatants were transferred into wells of a 96-well microtiter plate and then the absorbance of each well was measured at $541 \mathrm{~nm}$. $\square$, galactosylsphingosine; $\bigcirc$, sphingosylphosphorylcholine; + , stearic acid, galactosylceramide or sphingomyelin. 


\section{ACKNOWLEDGEMENTS}

We acknowledge the valuable discussions and encouragement of Dr. T. Nakamura and Dr. T. Yano of Kyushu University throughout this study. This work was supported in part by Research Fellowship of Japan Society for the Promotion of Science for Young Scientists and the Sasakawa Scientific Research Grant (K. K.).

\section{REFERENCES}

Hannun, Y. A. and R. M. Bell 1987 Lysosphingolipids inhibit protein kinase C: implications for the sphingolipidoses. Science 235, 670-674

Hiraishi, A. 1992 Direct automated sequencing of 16S rDNA amplified by polymerase chain reaction from bacterial cultures without DNA purification. Lett. Appl. Microbiol. 15, 210-213

Hoshina, T. 1962 On a new bacterium, Paracolobactrum anguillimortifemumn sp. Bull. Japan. Soc. Sci. Fish. 28, 162-164

Hugh, R. and E. Leifson 1953 The taxonomic significance of fermentative vesus oxidative metabolism of carbohydrates by various gram-negative bacteria. J. Bacteriol. 66, 24-26

Ito, M., T. Kurita and K. Kita 1995 A novel enzyme that cleaves the $N$-acyl linkage of ceramides in various glycosphingolipids as well as sphingomyelin to produce their lyso forms. J. Biol. Chem. 270, $24370-24374$

King, E. O., M. K. Ward and D. E. Raney 1954 Two simple media for the demonstration of pyocyanin and fluorescin J. Lab. Clin. Med. 44,301-307

Kita, K., T. Kurita and M. Ito (2001) Characterization of the reversible nature of the reaction catalyzed by sphingolipid ceramide $N$-deacylase: a novel form of reverse hydrolysis reaction. Eur. J. Biochem. $\mathbf{2 6 8}, 592-602$

Kovacs, N. 1956 Identification of Pseudomonas pyocyanea by the oxidase reaction. Nature 178, 703

Krieg, N. R. 1984 Bergey's Manual of Systematic Bacteriology. Krieg, N. R and Holt, J. G. ed. vol. 1 Williams \& Wilkins, Baltimore.

Marmur, J. 1961 A procedure for the isolation of deoxyribonucleic acid from micro-organisms. J. Mol. Biol. 3, 208-218

Mitsutake, S., K. Kita, T. Nakagawa and M. Ito 1998 Enzymatic synthesis of ${ }^{14} \mathrm{C}$-glycosphingolipids by reverse hydrolysis reaction of sphingolipid ceramide $N$-deacylase: detection of endoglycoceramidase activity in a seaflower. J. Biochem. 123, 859-863

Shewan, J. M., W. Hodgkiss and J. Liston (1954) A method for the rapid differentiation of certain non-pathogenic, asporogenous bacilli. Nature 173, 208-209

Sueyoshi, N., H. Izu and M. Ito 1997 Preparation of a naturally occurring D-erythro-(2S, 3R)- sphingosylphosphocholine using Shewanella alga NS-589. J. Lipid Res. 38, 1923-1927

Sueyoshi, N., T. Maehara and M. Ito 2001 Apoptosis of Neuro2a cells induced by lysosphingolipids with naturally occurring stereochemical configuration. J. Lipid Res. 42, 1197-1202

Sugiyama, E., K.-I. Uemura, A. Hara and T. Taketomi (1990) Effects of various lysosphingolipids on cell growth, morphology and lipid composition in three neuroblastoma cell lines. Biochem. Biophys. Res. Commun. 169, 673-679

Taketomi, T. and N. Kawamura 1970 Preparation of lysohematoside (neuraminyl-galactosyl-glucosylsphingosine) from hematoside of equine erythrocyte and its chemical and hemolytic properties. $J$. Biochem. 68, 475-485

Tamaoka, J. and K. Komagata 1984 Determination of DNA base composition by reverse-phase high-performance liquid chromatography. FEMS Microbiol. Lett. 25, 125-128

Thompson, J. D., D. G. Higgins and T. J. Gibson 1994 CLUSTAL W: improving the sensitivity of progressive multiple sequence alignment through sequence weighting, position-specific gap penalties and weight matrix choice. Nucleic Acids Res. 22, 4673-4680.

Wakabayashi, H. and S. Egusa 1972 Characteristics of a Pseudomonas sp. from an epizootic of pond-cultured eels (Anguilla japonica). Bull. Japan. Soc. Sci. Fish. 38, 577-587 